\title{
Microclimatic changes in cultivating systems for the production of Collard greens baby leaf
}

\author{
Alterações microclimáticas em sistemas de cultivo para produção de \\ baby leaf de couve
}

\author{
Gustavo Castilho BERUSKI ${ }^{1}$; Rosana Fernandes OTTO²; Jhone de Souza ESPÍNDOLA ${ }^{3}$ \\ ${ }^{1}$ Autor para correspondência - Mestre - Universidade de São Paulo, Campus "Luiz de Queiroz". ESALQ - Escola \\ Superior de Agricultura Luiz de Queiroz, Doutorando em Engenharia de Sistemas Agrícolas. São Dimas - Piracicaba, \\ SP - Brasil. Endereço eletrônico: beruskigc@usp.br \\ ${ }^{2}$ Doutora - Universidade Estadual de Ponta Grossa, Setor de Ciências Agrárias e de Tecnologia, Departamento de \\ Fitotecnia e Fitossanidade. Av. Carlos Cavalcanti, 4748. Uvaranas - Ponta Grossa, PR - Brasil. rfotto@uepg.br \\ ${ }^{3}$ Mestre - Faculdade Integrado, Departamento de Agronomia. Rodovia BR 158, Km 207 - Campo Mourão, PR - Brasil. \\ jhone.souza@grupointegrado.br
}

Recebido em: 29-01-2015; Aceito em: 17-08-2015

\begin{abstract}
With the growing demand for products beneficial to human health, olericulturists developed the marketing of baby leaf. Various cultivation environments provide microclimatic changes, which in turn will change the entire development of plants. Thus, the work aimed to study the productive response of collard greens baby leaf in four cultivations systems [low tunnels with plastic (PT) and with sombrite (SB), nonwoven floating system (NW) and natural environment (NE)] and at five harvest times [21; 28; $35 ; 42$ and 49 days after sowing (DAS)]. The experiment was conducted in Ponta Grossa - PR, between 09-01 and 10-20-2011. At 14 DAS was held thinning, keeping the density of 500 plants $\mathrm{m}^{-2}$. At each moment of harvest, it were evaluated the number of leaves per plant (NL), plant height (PH), fresh (FM) and dry (DM) phytomasses of the plants, leaf area index (LAl) and productivity at the final collection point. The average air temperature (Ta) and photosynthetically active radiation (PAR) were monitored in each cultivation environment. Throughout the growing season it was found rapid growth of plants grown under PT compared to SB, characterized by greater accumulation of FM and DM. The baby leaf cultivation in the PT environment showed four days precocity in the harvest in relation to the NW, six days in NE and eight days for plants grown under SB. The low PAR radiation values within the SB environment interfered with the growth and development of the plants grown therein.
\end{abstract}

Additional keywords: Brassica oleracea var. acephala, nonwoven, plastic tunnel, protected cultivation, shade tunnel.

\begin{abstract}
Resumo
Com a crescente demanda por produtos benéficos a saúde humana, olericultores desenvolveram a comercialização de baby leaf. Diversos ambientes de cultivo proporcionam alterações microclimáticas, que por sua vez alterarão todo desenvolvimento das plantas. Assim, o trabalho objetivou estudar a resposta produtiva de baby leaf de couve Comum em quatro sistemas de cultivo [túneis baixos com plástico (PT) e com sombrite (SB), cobertura direta com agrotêxtil (NW) e ambiente natural (NE)] e em cinco momentos de colheita [21; 28; 35; 42 e 49 dias após a semeadura (DAS)]. O experimento foi conduzido em Ponta Grossa - PR, entre 10-09 e 20-10-2011. Aos 14 DAS realizou-se o desbaste, mantendo a densidade de 500 plantas $\mathrm{m}^{-2}$. Em cada momento de colheita, avaliou-se o número de folhas por planta (NL), altura das plantas $(\mathrm{PH})$, fitomassas fresca (FM) e seca (DM) das plantas, o índice de área foliar (LAI) e a produtividade no ponto de colheita final. A temperatura média do ar (Ta) e a radiação fotossinteticamente ativa (PAR) foram monitoradas em cada ambiente de cultivo. Ao longo do ciclo de cultivo constatou-se rápido crescimento das plantas cultivadas sob PT comparadas a SB, caracterizado pelo maior acúmulo de FM e DM. O cultivo de baby leaf sob o ambiente PT apresentou precocidade na colheita de quatro dias em relação à NW, seis dias em NE e oito dias para as plantas cultivadas sob SB. Os baixos valores de radiação PAR no interior do ambiente SB interferiram no crescimento e no desenvolvimento das plantas ali cultivadas.
\end{abstract}

Palavras-chave adicionais: agrotêxtil, Brassica oleracea var. acephala, cultivo protegido, túnel plástico, túnel com sombrite. 


\section{Introduction}

The consumer market of vegetables is increasingly demanding, always looking for products with high quality and that are beneficial to human health. Seeking to meet the demand of the consumer market, olericulturists developed a new type of marketing of vegetables called Baby leaf or young leaves.

Baby leaf is the product characterized by young leaves of vegetables, which do not present the full expansion of the leaf blade. The commercial product is harvested early in relation to the cycle of these vegetables when produced for traditional consumption and, therefore, various olericultural crops can be used, such as lettuce, collard greens, peas and beets, because there is only interest in the production of the small leaves (ISLA, 2013).

In addition to providing attractive leaves due to the reduced size and distinctive flavor, baby leaf has other advantages in relation to the vegetables of normal cycle, such as larger percentage of usable product, easy preparation of the leaves for consumption and minimal oxidation of the leaves due to the smaller diameter of the stem. Furthermore, the rates of physiological changes are reduced, since plants in complete stage of development are more likely to be damaged during preparation, and there may be changes in color, texture and flavor, reducing the commercial value and the storage period (Martínez-Sánchez et al., 2012).

In Brazil there is a lack of studies to determine the most suitable production system for baby leaf cultivation, including with respect to possible types of plant covers. The intensity of the changes of microclimatic parameters, such as air and soil temperature, relative air humidity and solar radiation vary according to the type of protected environment, whether being greenhouses (Blat et al., 2011), direct nonwoven on plants (Feltrim et al., 2006; Pereira et al., 2003) or low tunnels (Barros Júnior et al., 2004).

The scarcity of studies with baby leaf in Brazil is even greater when it comes to the production with direct sowing in the soil and the most appropriate management for this production system. Recent work on the production of baby leaf (Otto et al., 2011; Oliveira et al., 2009; Purquerio et al., 2010) portray the cultivation in trays with different volumes of cells, whose cultivation type is expensive compared to the cultivation in the system of direct sowing in the ground, whether it is in a protected environment or not.

Considering the lack of studies for the baby leaf cultivation in field and under protected environments and the lack of knowledge of microclimatic changes that different cultivation environments provide in the growth and development of plants, it was aimed with this study to evaluate the changes induced in average air temperature and photosynthetically active radiation and the productive responses of baby leaf of Collard greens (Brassica oleracea var. acephala), cultivar Georgia, under different cultivation systems in the city of Ponta Grossa, Paraná.

\section{Material and methods}

The experiment was conducted at the School Farm Capão da Onça, belonging to the State University of Ponta Grossa, Ponta Grossa - PR (altitude of $850 \mathrm{~m}, 25^{\circ} 5^{\prime} 37^{\prime \prime} \mathrm{S}$ and $50^{\circ} 03^{\prime} 35^{\prime \prime} \mathrm{W}$ ). The local climate is classified by Köppen as Cfb. The soil was classified as Dystrophic Cambisol with clay texture. Prior to the installation of the experiment, it was performed the chemical analysis of the soil of the experimental area (Table 1), being then dispensed the correction and base fertilization of the soil of the experimental area, for being a short-cycle culture and with small-size plants.

The soil was previously prepared making use of rotary tiller, being subsequently raised planting beds $30 \mathrm{~m}$ long and $1.20 \mathrm{~m}$ wide and these were covered beforehand with black polyethylene for a period of 60 days in order to reduce the weed population. Previous to the installation of the experiment, the cover was removed, the planting beds were leveled with rake and the seeds were sown.

Table 1 - Chemical analysis of the soil before implantation of the experiment. Ponta Grossa, UEPG, 2011.

\begin{tabular}{cccccccccc}
\hline $\begin{array}{c}\text { Depth } \\
(\mathrm{cm})\end{array}$ & $\mathrm{pH}\left(\mathrm{CaCl}_{2}\right)$ & $\begin{array}{c}\mathrm{H}+\mathrm{Al}^{+3} \\
-------\mathrm{Al}^{3}\end{array}$ & $\begin{array}{c}\mathrm{Ca}^{2+} \\
\left(\mathrm{cmol}_{\mathrm{c}} \mathrm{dm}^{-3}\right)\end{array}$ & $\begin{array}{c}\mathrm{Mg}^{2+} \\
--------\mathrm{K}^{+}\end{array}$ & $\begin{array}{c}{ }^{(1)} \mathrm{P} \\
\left(\mathrm{mg} \mathrm{dm}^{-3}\right)\end{array}$ & $\begin{array}{c}\mathrm{C} \\
\left(\mathrm{g} \mathrm{dm}^{-3}\right)\end{array}$ & $\begin{array}{c}\mathrm{V} \\
(\%)\end{array}$ \\
\hline $0-20$ & 5.2 & 6.2 & 0.0 & 5.9 & 2.3 & 0.8 & 50.8 & 30 & 59.6 \\
\hline
\end{tabular}

(1) $\mathrm{P}$ extraction with Mehlich-1 solution.

The experimental design was randomized blocks with treatments distributed in split plots, with four replications. The main factor was cultivation systems, being Natural Environment (NE); Low tunnel with 100 microns polyethylene (PT); Low tunnel with Sombrite $70 \%$ (SB) and direct Nonwoven (NW) (white, $25 \mathrm{~g} \mathrm{~m}^{-2}$ weight). As a secondary factor, five harvest times $(21,28,35,42$ and 49 days after sowing - DAS) were evaluated.
The experimental area was cultivated with Georgia Collard greens (ISLA). Seeds were sown on 09-01-2011, with eight rows of crops in each plot, in spacing of $0.02 \mathrm{~m}$ between plants and $0.10 \mathrm{~m}$ between rows, resulting in 500 plants $\mathrm{m}^{-2}$.

The tunnels were mounted with arches of PVC pipes with $1 / 2$ inch in diameter and spaced every $1.5 \mathrm{~m}$. The tunnels were $1.0 \mathrm{~m}$ in height at the center of the arc, with $1 \mathrm{~m}$ width and $5 \mathrm{~m}$ length. 
The protection of plants using nonwoven was held in the floating blanket system, being attached to the ends and sides with iron clamps. The plants remained protected with the protective material throughout the growing season, being removed only to the achievement of cultivation. The nonwoven is made from polypropylene filaments which are grouped in layers and welded together by temperatures, thus becoming a light product and of acceptable resistance for using in agriculture (Gregoire, 1992).

The irrigation system used in the experimental area was sprinkling, being activated whenever necessary for the soil moisture to remain close to the field capacity. Plastic tunnels were kept open at the time of irrigation. The weed control was carried out by manual weeding, whenever necessary to prevent interspecific competition. During the experiment it was not necessary to perform control of pests and/or diseases.

Measures of the photosynthetically active radiation (PAR) (sensor above the plant canopy) and air temperature (sensor $20 \mathrm{~cm}$ from the ground) in the cultivating environments were held respectively by sensors LI190SB Quantum Sensor (LI-COR) and of temperature (107 Temperature Probe), coupled to "Datalloger" (CR23x - Campbell Scientific Inc.). The system was programmed to perform readings every minute, storing the hourly average. The PAR fraction was measured using a Quantum sensor, LI-190SB model, of spectral response in the range between 0.4 and $0.7 \mu \mathrm{m}$, also from LI-COR brand, installed 2 meters above the ground level. PAR values were initially recorded on instantaneous measurement unit $\left(\mu \mathrm{mol} \mathrm{m} \mathrm{m}^{-2} \mathrm{~s}^{-1}\right)$ and were subsequently integrated throghout the day and transformed into $\mathrm{mol} \mathrm{m}^{-2}$ day ${ }^{-1}$ (Equation 1):

$$
\left.\operatorname{PAR}_{(\text {day })}=\sum \text { (daily } \operatorname{PAR}_{(\mathrm{s})}\right) \times \mathrm{t}_{(\mathrm{s})} \times 10^{-6}
$$

Where: $\operatorname{PAR}_{(\text {day })}$ and $\operatorname{PAR}_{(\mathrm{s})}$ are, respectively, the photosynthetically active radiation for the daily period $\left(\mathrm{mol} \mathrm{m}^{-2}\right.$ day $\left.^{-1}\right)$, and for second intervals $\left(\mu \mathrm{mol} \mathrm{m}^{-2} \mathrm{~s}^{-1}\right)$; $t_{(s)}$ is the time between collections, in seconds.

Subsequently, data were transformed and expressed in $\mathrm{MJ} \mathrm{m}^{-2}$ day-1 using a conversion value as proposed by Thimijan \& Heins (1983) (Beckmann et al., 2006) (Equation 2):

$$
\left.\operatorname{PAR}_{(\mathrm{MJ} \mathrm{m}}^{-2} \mathrm{day}^{-1}\right)=\operatorname{PAR}_{\left(\mathrm{mol} \mathrm{m}^{-2} \mathrm{day}^{-1}\right)} \times 4,57
$$

Five plants per subplot were harvested, being evaluated the characteristics plant height $(\mathrm{PH})$, number of leaves per plant (NL), fresh (FM) and dry (DM) phytomasses and leaf area index (LAl). The final yield was calculated when the plants reached the point of harvest. It was determined that the collard greens plants with 5 leaves per plant had suitable size for marketing as baby leaf, this being considered the point of harvest for plants.

Plant height was determined with the aid of graduated ruler $(\mathrm{cm})$, taking into account the interval between the neck of the plant and the upper part of the larger leaf. For the accounting of the number of leaves, it were considered those with length longer than $2 \mathrm{~cm}$ for each plant. The fresh and dry phytomasses were determined by weighing the shoots of the plant with aid of electronic precision balance. The still wet samples were taken to forced circulation oven with a temperature of $60^{\circ} \mathrm{C}$ until constant phytomass for determining dry phytomass. The leaf area index was calculated according to the equation:

$L A I=\frac{L A}{S}$

In which: LAl is the leaf area index, LA is the leaf area $\left(\mathrm{m}^{2}\right)$ and $S$ is the land area occupied by the sample $\left(m^{2}\right)$.

The leaf area values were obtained by leaf area integrator model LI 3000 (LI-COR). Finally, the productivity was obtained by multiplying the fresh phytomass by the number of plants of the useful area of the plot.

For the statistical analysis, it was used the SISVAR program. The original data were transformed into square root and subjected to analysis of variance and means compared by Tukey test at $5 \%$ probability. For variables with significant interactions was determined the regression equation by OriginPro 8 software, and the determination of the regression equation that best represents the crop growth data defined by the coefficient of determination $\left(R^{2}\right)$.

\section{Results and discussions}

For microclimatic changes occurring in the cultivation environments, it was found that the air temperature (Ta) under the nonwoven (NW) was higher when compared to the other environments, with mean values of $20.3^{\circ} \mathrm{C}$ throughout the crop cycle. For plastic tunnel environment (PT), natural environment (NE) and sombrite (SB), the average values were $18.5^{\circ} \mathrm{C}, 16.6^{\circ} \mathrm{C}$ and $15.9^{\circ} \mathrm{C}$, respectively (Figure $1-\mathrm{A}$ ). The higher Ta's inside PT and NW, throughout the crop cycle, compared to the SB environment, are associated with higher transmittance of solar radiation to the interior thereof.

The higher average Ta throughout the crop cycle inside the NW environment, compared to the other cultivation environments, is directly related to the lower volume of air that's inside of this cropping environment, a factor that affected the energy balance in the interior thereof. Basically, the energy balance is represented by the accounting between the energy entering and leaving a system and how much energy will be used by this system (Pereira et al., 2002). For the different systems evaluated, the available energy will be used in the heating of air and plants $(H$, sensible heat), in the soil heating $(G)$, in the evapotranspiration (LE, latent heat) and in the biological synthesis processes $(\mathrm{F})$.

In the NW cultivation environment, as the 
coverage material was disposed directly on the collard greens baby leaf plants, the volume of air was lower when compared to the other PT, NE and SB systems. Thus, the $\mathrm{H}$ fraction of the energy balance heated more quickly and intensely the volume of air within that environment, with consequent increase of the average temperatures in the NW.
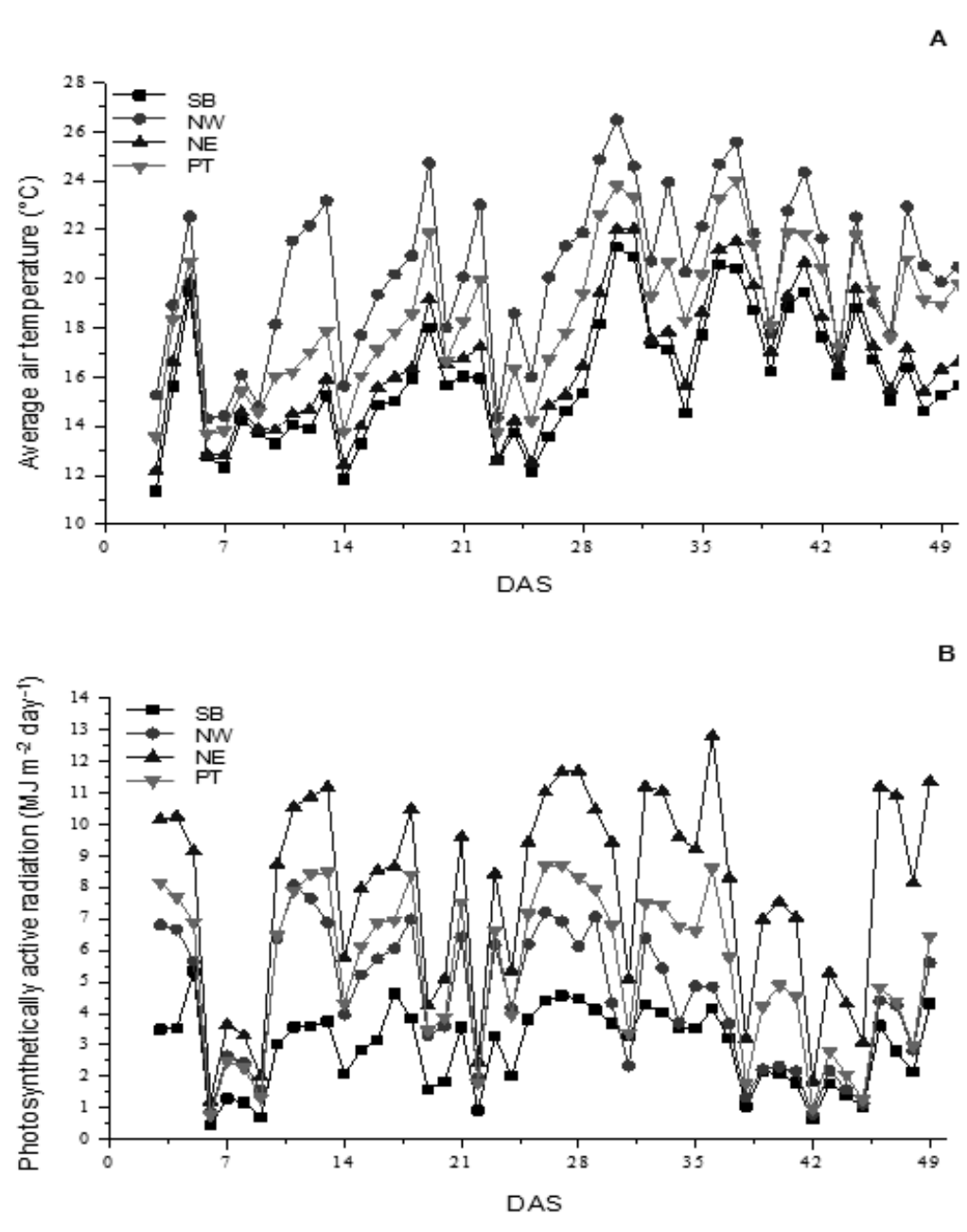

Figure 1 - Average air temperature (A), Photosynthetically Active Radiation (B), under plastic tunnels (PT), sombrite (SB), nonwoven (NW) and in natural environment (NE), throughout the crop cycle of collard greens baby leaf. Ponta Grossa, UEPG, 2011.

The lowest values of $\mathrm{Ta}$, throughout the crop cycle, were recorded in SB. This is due to the nature of the cover that promotes shading, significantly reducing the entry of solar radiation. The reduction in the passage of solar radiation through the cover also decreases the amount of radiation that reaches the surface, being responsible for $G$ and then $H$, thus lowering the temperatures within the SB environment when compared to the other environments.

In protected environments, the natural radiation balance has considerable modification, since the cover absorbs and reflects part of the incident radiation, the rest being transmitted into the environment. Hence, the solar radiation will affect other components of the energy balance, such as $\mathrm{H}$ and $\mathrm{G}$, which consequently interferes either positively or negatively in the values of air and soil temperature (Pezzopane et al., 2004).

The relationship between the photosyntheti- cally active radiation in and out of the different cultivation environments represents the transmissivity of the material used as cover. These values ranged between $36 \%$ and $69 \%$, depending on the nature of the material. The average values of PAR radiation throughout the crop cycle were 7.86; 5.43; 4.45 and $2.89 \mathrm{MJ} \mathrm{m}^{-2}$ day $^{-1}$ for NE, PT, NW and SB, respectively (Figure 1-B).

Tullio et al. (2013), analyzing the beet cultivation in different cropping environments during the summer season in the city of Ponta Grossa, PR, found that the PAR fraction of the global solar radiation also showed an average reduction of $28 \%$ in the environment of low tunnel with sombrite black shade netting of $70 \%$ compared to the natural environment. A similar trend was observed by Scuderi et al. (2012), wherein the use of different screen environments, with increases in shading levels, reduced the passage of the photosynthetically active radiation, decreasing the 
amount of radiation available for use in the processes of growth and development of plants grown under these environments.

The interaction between cultivation system and harvest times was significant for the analyzed characteristics. For NL (Figure 2-A), it was verified, throughout the crop cycle, that the crops under NW and PT showed plants with higher $\mathrm{NL}$ compared to those grown in NE and SB, featuring major development of plants under NW and PT, in all harvest periods. This performance is related to the higher temperatures found in NW and PT throughout the crop cycle (Figure 1-A). Although the values of incident PAR radiation under NW and $\mathrm{PT}$ were lower than those found in NE, the thermal gain favored the metabolism of plants resulting in increased NL (Figure 2-A).

Associated with the thermal gain, under shading conditions plants can undergo morphologi- cal changes, according to Bezerra Neto et al. (2005), analyzing the production of lettuce seedlings, reductions in light intensity inside the protected environments can induce a rearrangement of chloroplasts toward the leaf surfaces with greater exposure to light, allowing maximum absorption of the incident light, maximizing the photosynthetic process.

At 42 DAS only plants grown under PT reached the point of harvest (5 leaves per plant). In the other cultivation environments, the harvest point was reached at 46, 47 and 48 DAS in NW, NE and SB, respectively. The precocity of collard greens plants grown under $\mathrm{PT}$ is related to the average air temperature values more suitable to the plant development (Figure 1-A), accelerating the metabolic reactions and thus the vegetative growth.
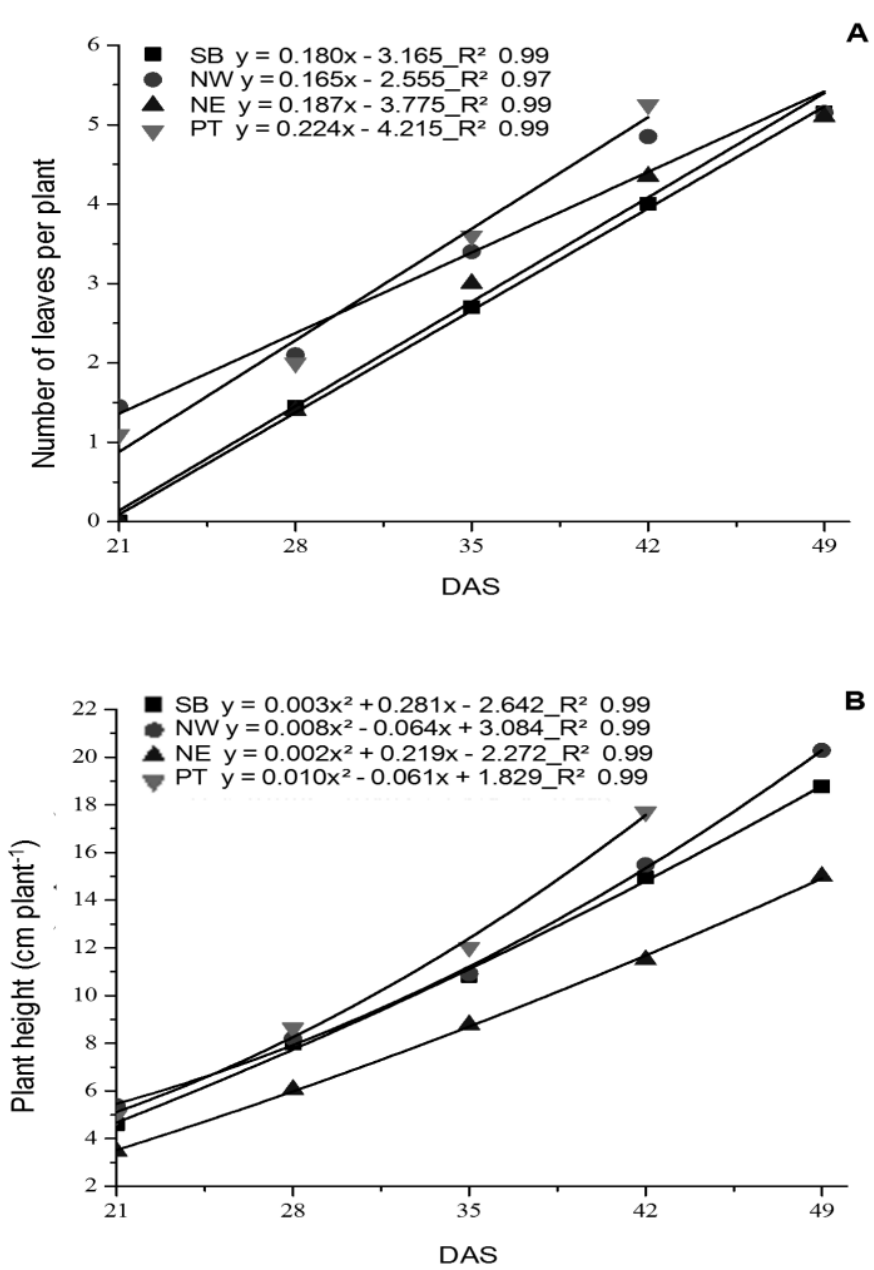

Figure 2 - Number of leaves per plant $(A)$ and evolution of plant height $(B)$ of collard greens baby leaf grown under plastic tunnels (PT), sombrite (SB), nonwoven (NW) and in natural environment (NE) in different harvest seasons. Ponta Grossa, UEPG, 2011.

Although working with lettuce plants until the end of the cycle, Otto et al. (2013) also found that the cultivation under the PT and NW environments had precocity of 21 days in harvesting, in both cultivation systems, compared to cultivation in natural environment and on screen environments with Aluminet $40-\mathrm{O} B$, red ChromatiNet ${ }^{\circledR}$ 40. According to the authors, the shading materials provided envi- 
ronments with better levels of radiation and thermal regimes appropriate to favor the metabolism of lettuce plants grown within these environments.

Considering that the collard greens baby leaf plants showed better conditions for growth under PT environment, it can be considered that Ta around 18 ${ }^{\circ} \mathrm{C}$ (average throughout the crop cycle) is ideal for the production of collard greens baby leaf.

The cultivation system NE presented plants with lower heights throughout the crop cycle compared to the other cultivation environments (Figure 2-B). After 28 DAS, plants grown under PT had higher height (Figure 2-B), as well as values of FM (Figure 3-A), DM (Figure 3-B) and LAI (Figure 4) higher than the other cultivation environments, featuring that there was actually greater accumulation of photoassimilates in collard greens plants grown under PT.

Plants grown in NE and under NW had similar performances for DM and LAI in their respective sampling points, but this response was not observed in the values of FM, where the plants under NW showed high values compared to those grown in NE. The increase in FM of plants grown under NW did not correspond to an increase of plant matter, but rather to the accumulation of water in plant tissues, featuring plant etiolation. This result is possibly related to the values of incident PAR radiation under NW (Figure 1-B), with mean value of $4.45 \mathrm{MJ} \mathrm{m}^{-2}$ day $^{-1}$, very close to the trophic limit of vegetables that is approximately $4.2 \mathrm{MJ} \mathrm{m}^{-2}$ day $^{-1}$, ie, with radiation values below this value, plants do not produce the minimum of photoassimilates necessary to their maintenance.

According to FAO (1990), the trophic limit for most plants is approximately $8.4 \mathrm{MJ} \mathrm{m}^{-2}$ day $^{-1}$. Taking into account that the photosynthetically active radiation is comprised within the spectral range of 0.4 to $0.7 \mu \mathrm{m}$ and is equal to approximately $50 \%$ of the global radiation (Pereira et al., 2002), it was determined the value of photosynthetically active radiation equivalent to the trophic limit proposed by FAO (1990), but using the PAR radiation values.
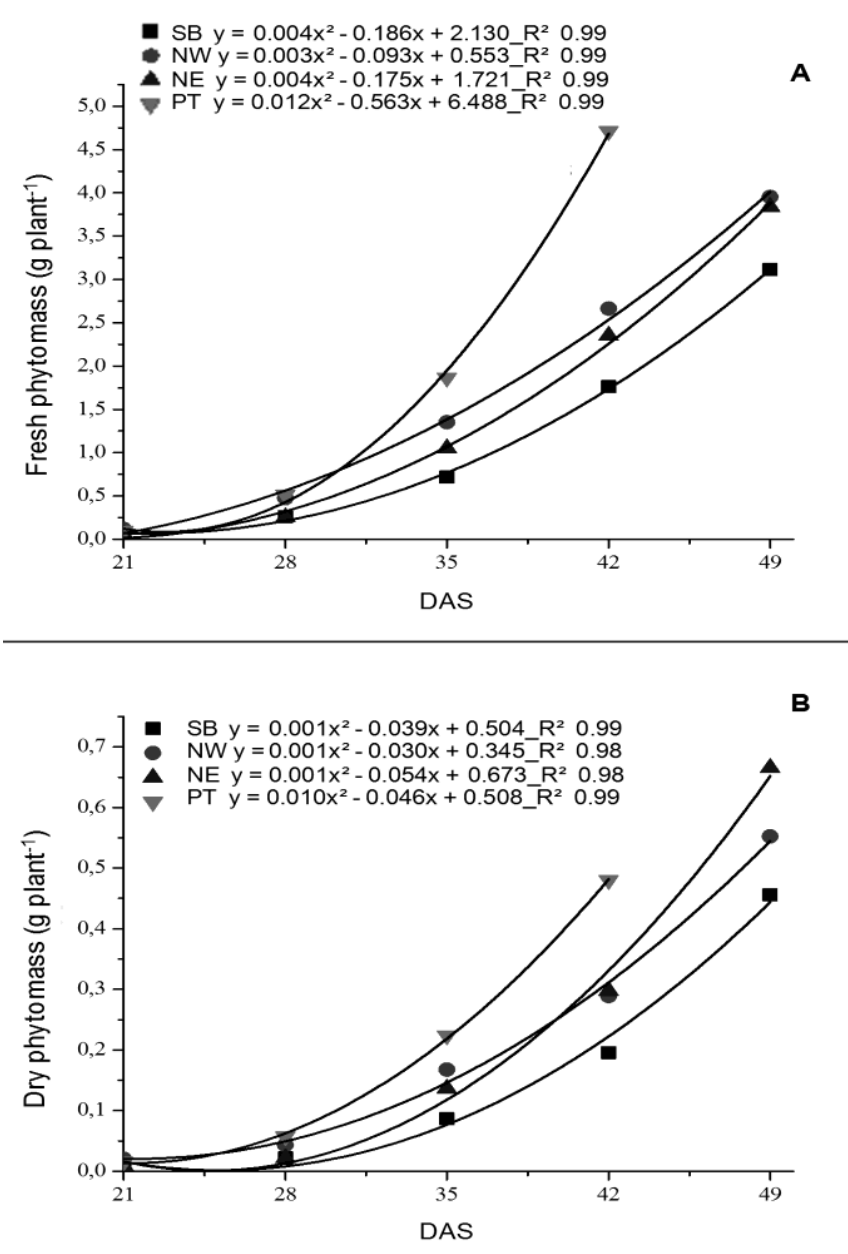

Figure 3 - Evolution of fresh $(A)$ and dry $(B)$ phytomasses of collard greens baby leaf plants grown under plastic tunnels (PT) and with sombrite (SB), under nonwoven (NW) and in natural environment (NE) in different harvest seasons, Ponta Grossa, UEPG, 2011.

Still analyzing the FM and DM in SB, it was found that, throughout the crop cycle, such factors presented lower values than in the other cultivation systems, showing that the plants had reduced growth in SB. However, the same performance was not seen for the leaf area index. The LAl of plants grown under 
SB showed similar growth to those grown in other cultivation systems, resulting in similar values of leaf area compared to the other cultivation systems when the point of harvest was reached. The result is associated with water accumulation in the tissues of plant cultured under SB, in order to expand the leaf area to intercept more light to lessen the effect of reduced values of PAR radiation. The water accumulation in plant tissues of plants grown in SB was visible in the post-harvest phase, where the plants showed wilting symptoms faster than those grown in other environments.

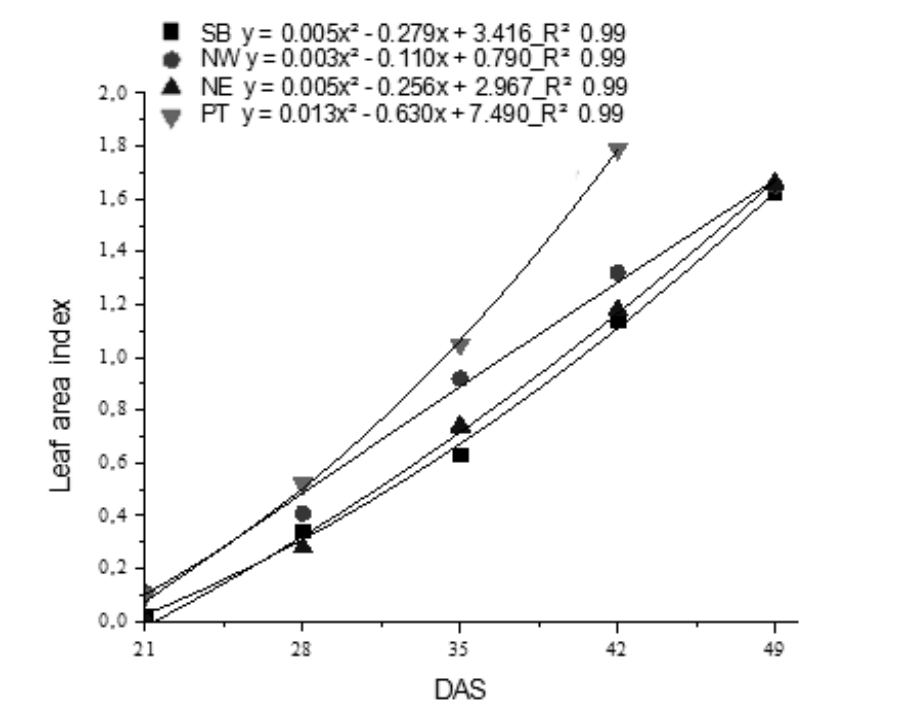

Figure 4 - Evolution of the leaf area index of collard greens baby leaf plants grown under plastic tunnels (PT), with sombrite (SB), under nonwoven (NW) and in natural environment (NE) in different harvest seasons. Ponta Grossa, UEPG, 2011.

To yield $\left(\mathrm{kg} \mathrm{m}^{-2}\right)$, it was considered the data of plants collected at 42 DAS for the environment with PT protection, 46 DAS for NW, 47 DAS for NE and plants collected at 48 DAS for SB, ie when plants were at the appropriate point for harvesting and marketing. Thus, it was found that the final yields were similar to plants grown in different cultivation environments, with values of $1.80 \mathrm{~kg} \mathrm{~m}^{-2}$ for PT, $1.33 \mathrm{~kg} \mathrm{~m}^{-2}$ in NW, $1.17 \mathrm{~kg} \mathrm{~m}^{-2}$ in $\mathrm{NE}$ and $1.55 \mathrm{~kg} \mathrm{~m}^{-2}$ in SB environment. Even without statistically significant differences, it was found that plants grown under PT showed earliness in harvesting as mentioned before, which is considered interesting in the cultivation of vegetables.

\section{Conclusions}

It is possible to produce collard greens baby leaf in different cultivation systems, however, the use of plastic tunnel as coverage material results in earliness in the harvest of plants of up to 6 days, which makes it advantageous for the producer.

Photosynthetically active radiation (PAR) values within low tunnel with sombrite $70 \%$ environment favor the etiolation of plants reducing the post-harvest period.

The average air temperature values close to $18^{\circ} \mathrm{C}$, recorded within low tunnel with plastic environment, provided the best thermal conditions for the cultivation of collard greens baby leaf in the Ponta Grossa-PR region.

\section{Acknowledgements}

The Higher Education Personnel Improvement Coordination (CAPES) for the financial support during the course of this study.

\section{References}

Barros Júnior AP, Grangeiro LC, Bezerra Neto F, Negreiros MZ, Souza JO, Azevedo PE, Medeiros DC (2004) Cultivo da alface em túneis baixos de agrotêxtil. Horticultura Brasileira 22(4):801-803.

Beckmann MZ, Duarte GRB, Paula VA, Mendez MEG, Peil RMN (2006) Radiação solar em ambiente protegido cultivado com tomateiro nas estações verão-outono no Rio Grande do Sul. Ciência Rural 36(1):86-92.

Bezerra Neto F, Rocha HCR, Rocha CCR, Negreiros MZ, Leitão M de MVBR, Nunes GHS, Espínola JS, Queiroga RCF (2005) Sombreamento para produção de mudas de alface em alta temperatura e ampla luminosidade. Horticultura Brasileira 23(1):133-137.

Blat SF, Sanchez SV, Araújo JAC, Bolonhezi D (2011) Desempenho de cultivares de alface crespa em dois ambientes de cultivo em sistema hidropônico. Horticultura Brasileira 29(1):135-138.

Feltrim AL, Cecílio Filho AB, Rezende BLA, Barbosa JC (2006) Produção de chicória em função do período de cobertura com tecido de polipropileno. Horticultura Brasileira 24(2):249-254. 
FAO - Food and Agriculture Organization of the United Nations (1990) Protected cultivation in the Mediterranean climate. Roma: FAO. 313p. (Plant Production and Protection Paper - 90).

Gregoire PH (1992) Los no tejidos protección contra los insetos y los virus. In: XII Congresso Internacional de Plásticos en Agricultura. Granada. Actas... Granada, p. E11- E18.

ISLA Sementes Ltda. (2013) Descubra o que é baby leaf. Disponível em: http://isla.com.br/cgibin/artigo.cgi/descubra-o-que-e-

babyleaf/?id_artigo=566. (Acesso em: 15 nov. 2013).

Martínez-Sánchez A, Luna MC, Selma MV, Tudela JA, Abad J, Gil MI (2012) Baby-leaf and multi-leaf of green and red lettuces are suitable raw materials for the fresh-cut industry. Postharvest Biology and Technology 63(1):1-10.

Oliveira F, Baqueiro LHR, Rocha MAV, Tivelli SW, Purquerio LFV (2009) Produção de baby leaf de alface em bandejas com diferentes volumes de células. Horticultura Brasileira 27(supl.):S3111-S31155.

Otto RF, Ohse S, Torres AL (2011) Produção de "baby leaf" de alface em sistema "floating" sob diferentes ambientes de cultivo. Horticultura Brasileira 29(supl.):S165-S171.

Otto RF, Niesing PC, Cortez MG, Oliveira AE (2013) Microclimatic modifications and productive responses of the lceberg lettuce (Lactuca sativa) in protected environments. Revista Ciência Agronômica 44(4):878-884.
Pereira AR, Angeloci LR, Sentelhas PC (2002) Agrometeorologia - Fundamentos e aplicações práticas. Guaíba: Agropecuária. 478p.

Pereira AV, Otto RF, Reghin MY (2003) Respostas do feijão-vagem cultivado sob proteção com agrotêxtil em duas densidades de plantas. Horticultura Brasileira 21(3):564-569.

Pezzopane JEM, Oliveira PC, Reis EF, Lima JS de S (2004) Alterações microclimáticas causadas pelo uso de tela plástica. Engenharia Agrícola 24(1):9-15.

Purquerio LFV, Baqueiro LHR, Sanches J, Tivelli SW, Cia P (2010) Produção de baby leaf de rúcula em diferentes volumes de células no outono. Horticultura Brasileira 28(supl.):S1505-S1511.

Scuderi D, Giuffrida F, Toscano S, Romano D (2012) Growth, physiological response, and quality characteristics of weeping fig in response to shading levels and climatic conditions. HortScience 47(11):1586-1592.

Thimijan RW, Heins RD (1983) Photometric, radiometric and quantum light units of measure: a review of procedures for interconversion. HortScience 18(2):818-822.

Tullio JA, Otto RF, Boer A, Ohse S (2013) Cultivo de beterraba em ambientes protegido e natural na época de verão. Revista Brasileira de Engenharia Agrícola e Ambiental 17(10):1074-1079. 